\title{
The impact of EFL teachers' prior language learning experiences on their cognition about teaching grammar
}

\author{
Rayati Damavandi, Rajabali \\ University of Mazandaran, Iran (alirayat@yahoo.com) \\ Roshdi, Mina \\ University of Mazandaran, Iran (Minaroshdi7@yahoo.com)
}

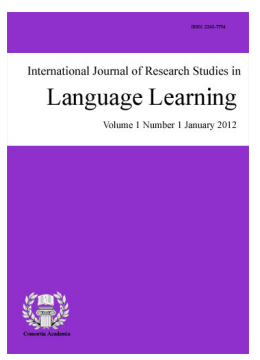

ISSN: $2243-7754$

Online ISSN: 2243-7762

Received: 12 November 2012 Available Online: 6 April 2013

\section{Abstract}

There is now a considerable body of evidence to emphasize that prospective teachers' cognition and education are highly influenced by their beliefs about teaching and learning, which in turn are defined by their personal history and learning experiences in classrooms. However, little has been said about the possible effect of such beliefs and experiences on practicing teachers. To address this gap, the present paper set out to investigate Iranian EFL teachers' beliefs about teaching grammar and to determine to what extent their current beliefs are influenced by their prior language learning experiences, their teacher education courses, and their teaching experiences. Analyses of data drawn from a questionnaire given to 40 experienced English teachers in an English language teaching institute and a semi-structured interview of 14 teachers from the same sample revealed a significant contribution of prior language learning experiences in the formation of the teachers' (pre)conceptions about teaching grammar. These experiences were found to be as influential in the construction of teachers' beliefs as the teachers' own teaching experiences and also proved to be much more significant than their teacher education courses.

Keywords: apprenticeship of observation; teacher cognition; teacher education; teaching experience 


\section{The impact of EFL teachers' prior language learning experiences on their cognition about teaching grammar}

\section{Introduction}

During the late 1980s English language teaching profession witnessed a movement away from transmission, product-oriented theories to constructivist process-oriented theories of learning and teaching (Crandall, 2000) which offered a means to exploring teaching from teachers' own personal perspectives. The advent of 'person-centered' paradigm (Atay, 2004) and teacher cognition studies during the last couple of decades paved the way for the reconceptualization of many familiar concepts in educational studies including teachers' learning.

Within constructivists' theories, teacher learning is defined by the interaction of what teachers may bring to their learning process and the content they encounter with during a teacher education program (S. Borg, 2006). In the literature focusing on the latter, teachers' preconceptions or prior learning experiences about learning and teaching have been introduced as an essential contributory factor which is grounded in their schooling memories as students and which may inform their cognition and act as a filter in teacher education courses, and affect their subsequent practices as a teacher (Arioğul, 2007; S. Borg, 2006).

The findings of several studies in this field (e.g. Donaghue, 2003; S. Borg, 2006; Hammerness et al., 2005) have also documented that since teacher learning often requires that teachers come to think about their profession in ways quite different from what they have learned from their own experiences as students, they may confront with learning blocks or at least well-established filters throughout the process of becoming professionals due to their preconceptions developed during schooling years. Therefore, it seems justifiable to argue that for teacher education to be effective, a rich understanding of teachers' preconceptions about learning and teaching acquired through their vast experiences of schooling will be inescapable.

\section{Schooling experiences: their Power and Limitations}

Teachers' cognition, which consists of their 'beliefs, thoughts and knowledge' is formed and influenced by various factors including their prior beliefs and experiences (S. Borg, 2003a, 2003b). Defined as teachers' "personal history and specific experiences of classrooms" (S. Borg, 2006, p. 283), the notion of prior language learning experiences (PLLEs) or schooling experiences has been of widespread currency in teacher education since early 1980s (Freeman, 2002). In teacher education studies, it is now widely accepted that prospective teachers bring a wealth of knowledge, prior experiences and 'established conceptions of teaching and learning' to their teacher preparation programs (S. Borg, 2006; Farrell, 2006; Johnson, 1999; Peacock 2001). These 'messy constructs' (Pajares, 1992) or tacit preconceptions (Kagan, 1992), "function as de facto guides for teachers" (Freeman, 1992 as quoted in S. Borg, 2003b, p. 88), inform their cognitions and provide them with an overall, rich, and diverse store of knowledge so that the candidates of teaching are differentiated from those novices learning other professions, such as candidates of medicine and law (M. Borg, 2004).

The sociologist Dan Lortie (1975) used the term 'apprenticeship of observation' to refer to a period in which many of early preconceptions prospective teachers hold about teaching have formed and established. Prior language learning experiences have also been interpreted as 'pre-training knowledge' (Almarza, 1996), teacher factor' (Bailey et al., 1996), 'teacher biography or antecedent' (Reeves, 2009 in Aoulou, 2011) in the literature.

Almarza (1996) referred to teachers' prior learning as their own learning experiences as well as the way they were taught during their school years. Supporting the idea, Johnson (1999) stated that the apprenticeship of observation encompasses two types of memories: teachers' memories as a student and their memories concerning their former teachers. Further, in order to highlight the power these memories exert on different 
The impact of EFL teachers' prior language learning experiences on their cognition about teaching grammar

aspects of teaching, he stressed that 'unknowingly [they] become the basis of our initial conceptions of ourselves as teachers, influence our view of students, etc. and act as justification for our teaching practice' (p.19). Stressing on the significance of PLLEs as the foundation of teachers' conceptions, Peacock (2001) contends that they might exert a considerable influence on teachers' professional lives. In addition, Su (2012) sorting prior experience as an environmental factors highlights the significance of those experiences acquired in school days and places them among factors which undoubtedly affect teachers' educational beliefs. Moreover, Based on their review of over 300 studies, Wideen et al. (1998) mention in Wright (2010, p. 269) that 'pre-existing beliefs are relatively impervious to change in formal courses.'

The period of teacher watching, however, does not seem to lay the basis for informed assessment of teaching practice by students or motivate the development of their analytical orientations towards the work of teachers. This dilemma is addressed by M. Borg in her 2004 study titled 'the apprenticeship of observation' in which she stressed on prospective teachers' 'partial view' towards teaching since their conceptions of their job are formulated based on "their perceptions as a student rather than as a teacher, what Lortie $(1975$, p. 62) described as the problem of 'asymmetrical memories' grounded in the 'front stage' behaviors of teachers at the expense of their 'backstage' behaviours which have been imprinted blindly by students. Lortie contends that

Since students do not receive invitations to watch the teacher's performance from the wings; they are not privy to the teacher's private intentions and personal reflections on classroom events. Students rarely participate in selecting goals, making preparations, or post-mortem analyses. Thus, they are not pressed to place the teacher's actions in a pedagogically oriented framework (ibid).

In other words, holding such implicit, ungrounded beliefs stemming from blind emulation during school-days, 'teacher watchers' or apprentices have developed 'inappropriate images and inadequate expectations of teaching' (Karavas \& Drossou, 2010, p. 262) for years. However, regardless of their undesirable problematic features, these influential prior experiences amalgamated with knowledge form student teachers' evolving identity as a professional teacher (ibid).

Considering the power, limitations as well as their unique qualities for every individual teacher, teachers' prior language learning experiences and those so-called schooling memories should not be underestimated by either teacher educators or program designers in order to map out any comprehensive effective educational program for teachers.

As far as research on PLLEs is concerned, S. Borg's 2003b and 2006 reviews of literature seem to indicate a paucity of research in this area in general. Besides, the few studies carried out so far (e.g., Farrell, 2006; G. Almarza, 1996; Peacock, 2001) have been on the effect of PLLEs on prospective teachers' cognition, which point to the compelling evidence for their powerful influence on teacher cognition. Little has been mentioned in the literature about the possible long-term effect of PLLEs on practicing teachers' cognition (e.g. Arioğul, 2007; Golombek, 1988). Therefore, the present study aimed to address this gap in the field by exploring practicing teachers' beliefs to find out how far their schooling experiences may still pervade in their professional lives. In other words, in view of the preceding discussion this paper attempts to attend to the following research question. To what extent are EFL teachers' conceptions of teaching grammar shaped by their prior learning experiences as compared with teacher education and teaching experiences?

\section{Materials and methods}

As stated above, the research intended to investigate the teachers' cognition and the share of their prior language learning experiences in comparison with the impact of teacher education and teaching experience on their cognition. This could not be achieved unless an area of language would be chosen. Hence it was decided to focus on grammar, an area whose significance and necessity in second language teaching has been highlighted after a period of anti-grammar movement in 1980s (Hedge, 2000). 
Rayati Damavandi, R. \& Roshdi, M.

To do so, drawing on S. Borg's 2003b suggestion on the main themes in grammar teaching research, the researcher chose four major themes to learn about the participants' orientations towards these themes and the sources these orientations using a questionnaire and interviewing the participants.

$>$ Significance of grammar teaching

- Grammar teaching strategies

- Implicit/Explicit teaching of grammar

$>$ Deductive/inductive teaching of grammatical rules

$>\quad$ Treating grammatical errors

$>\quad$ Use of grammatical terminology

\subsection{Phase one}

\subsubsection{Questionnaire}

The questionnaire (see Appendix A) utilized in the study was one adopted from Burgess and Etherington (2002) study, which had originally been designed to learn about the ESP teachers attitude towards grammar and grammar teaching. There were two parts in the questionnaire. The first part demanded demographic information from the participants. And the main section of the questionnaire contained 15 statements and was in the form of a five-point Likert-type attitude scale. The participants were asked to express their opinions about grammar and grammar teaching by ticking the phrase representing their views (i.e., agree strongly, agree, undecided, disagree, disagree strongly).

Also in order to elicit the teachers' opinions concerning the sources of their beliefs about each of those four themes, an item with three choices was added to the original questionnaire. The three choices were based on S. Borg's 2006 model of teacher cognition, which are: a) learning experience b) teaching experience and, c) teacher education course(s). The participants were requested to write their comments in the form of written narratives. Moreover, to do away with the probable language barrier and have sufficient explanatory data from each participant, the participants were requested to write their comments in their L1, i.e., Farsi if possible.

\subsubsection{Participants}

The participants in the study were chosen from among the Iranian English language teachers teaching at a language institute with a centralized system of English language teaching. Those intending to teach at this institute are to attend a uniform, short-term teacher training course (TTC) as part of the requirements for teaching. An analysis of the demographic information obtained from the questionnaires revealed that all the participants were experienced EFL teachers (their teaching experiences ranged between 5 to 23 years, averaging about 9 years). The participants had also mentioned that they had attended at least one intensive teacher training course in order to start teaching at the institute.

\subsubsection{Procedure}

A hundred questionnaires were distributed among the target group teachers at three branches of the institute in two provinces. The teachers were told that they could respond to the questionnaires in their leisure time and spend as much time on it as deemed necessary. Out of all the questionnaires handed out, two-fifth, i.e., 40 were responded and returned to the researcher. 


\subsection{Phase two}

\subsubsection{Interview}

Contrary to the researcher's expectation, the respondents did not respond in writing to the most essential part of the questionnaire, i.e., the participants' views about the sources of their beliefs. They only limited themselves to ticking the choice which they thought to be related to the source of their beliefs, providing the researcher with no additional, qualitative information in support of the quantitative data. Hence, it was found advisable to pursue the data collection process in order to accumulate more documentary evidence in the form of reasons, examples, narratives, etc. in support of the attributions to the sources of the teachers' beliefs. Hence the participants were invited to attend a follow-up interview to this end. The major justification for applying this method was that it would allow the researcher to explore tacit and unobservable aspects of participants' mental lives. Interview gives teachers the opportunity and time to detail fully and freely their approaches to teaching from which their beliefs and their underlined bases might be revealed. In addition, as Best and Kahn (2006) explain 'in the area where human motivation is revealed through actions, feelings, and attitudes, the interview can be most effective' (p. 337).

As mentioned above, since the purpose of the second phase was to have the participants elaborate on their view about the sources of their beliefs about teaching grammar, a semi-structured interview was resorted to in the second phase of the study 14 out of those 40 participants who had attended in the first phase of the study agreed to be interviewed. It took the researcher about an hour to elicit fairly adequate information about each participant's belief about grammar and grammar teaching and, more importantly, to listen to their explanations about the role of 'schooling' as well as other sources of influence in the formation of their teaching philosophies. The interviews were recorded and transcribed for analysis.

\subsection{Data analysis}

Since the data were gathered in two phases, the findings of the study will be presented benefiting from both sources of information, i.e., the questionnaire and the interview, in combination. As far as the questionnaires were concerned, simple descriptive statistics was employed after the responded questionnaires were gathered to analyze the quantitative data. That is, first, the frequencies of responses to the statements concerning four main themes in grammar teaching and its subcategories were determined. Then, these frequencies were converted into percentage responses. It is worth mentioning that in order to simplify data analysis, the values of the two outside categories of the questionnaire i.e. 'strongly agree' and 'agree,' as well as 'disagree' and 'strongly disagree', were combined to yield just two percentage responses rather than four (Best \& Kahn, 2006). Tables Two through Six show the teachers' attitudes towards grammar, grammar teaching, use of grammatical terminology as well correction of grammatical errors.

As to the analysis of interviews, the obtained data were transcribed carefully and were read and reviewed twice by the researcher to depict initial commonalities and patterns in the study via preceding stage (Dörnyei, 2007). Based on the predetermined selective themes of the interview or 'template categories,' the content of transcriptions were studied and classified on the basis of meaning units and categories and subcategories derived from the participants' orientations towards those main themes and the origins of their orientations. An example of the interview analysis is provided in the following table. 
Rayati Damavandi, R. \& Roshdi, M.

\section{Table 1}

An example of the analysis of the interview

\begin{tabular}{|c|c|}
\hline Main theme & Teacher beliefs on grammar teaching \\
\hline (Selective) Category & Significance of grammar teaching \\
\hline (Emerged) Sub-category & The role of grammar \\
\hline Meaning unit & $\begin{array}{l}\text { I was lacking in confidence. I started to learn grammar and everything changed, } \\
\text { while I was learning grammar I gained more confidence }\end{array}$ \\
\hline $\begin{array}{l}\text { Teacher beliefs } \\
\text { (condensed meaning) }\end{array}$ & Grammar as 'confidence booster' \\
\hline
\end{tabular}

To increase reliability of data analysis the initial coding was reviewed and rechecked by an expert in the field of teacher education, and then the existing incongruence between the two analyses was negotiated and resolved. Then, the 'interview profiles' (Dörnyei, 2007) including interviewees' own words and descriptions of their experiences as a learner and a teacher was extracted by the researcher to display the representative explanations.

\section{Results}

\subsection{Participants' beliefs}

A glance at the percentages in Table Two, which had been designed to investigate the teachers' view on the role of grammar in second language development, indicates that the teachers were more inclined to assume that grammar plays a refinement role rather than being the main pillar of language. This can be evidenced from the fact that, in contrast to other options, a very strong majority of the participants $(82.5 \%)$ agreed that grammar is an 'optional add-on' (Burgess \& Etherington, 2002) learned knowledge through which a basic acquired knowledge can be refined. The data drawn from the interviews also to a significant extent ( 9 out of 14) supports the above findings; that is, making language productions more accurate, is a primary function of grammar. For instance, one teacher stated that 'if you want to speak accurately you must learn grammar... without grammar you cannot speak well (T1)'.

\section{Table 2}

The significance of grammar in second language development

\begin{tabular}{llcc}
\multicolumn{1}{c}{ Relevant items in the questionnaire (Q) } & Agree & $\begin{array}{c}\text { Disagree } \\
(\%)\end{array}$ & $\begin{array}{c}\text { Undecided } \\
(\%)\end{array}$ \\
\hline $1 \quad \begin{array}{l}\text { A framework for the rest of the language-a basic system to } \\
\text { build everything else on } \\
\text { The building blocks of language which are combined to form a } \\
\text { whole }\end{array}$ & 35 & 37.5 & 35 \\
$3 \quad \begin{array}{l}\text { An equal pillar in supporting language proficiency (other } \\
\text { pillars could be knowledge pronunciation appropriacy or } \\
\text { culture etc. }\end{array}$ & 50 & 17.5 & 32.5 \\
\hline $\begin{array}{l}\text { Something which is added on to language proficiency: it } \\
\text { makes language production more accurate. }\end{array}$ & 82.5 & 10 & 7.5 \\
\hline
\end{tabular}

As to the first subtheme of the second theme, i.e., whether grammar should be taught consciously, the trend seems to be away from isolation of grammatical items and their systematic, explicit presentation to more implicit teaching. In other words, while three-fourth of the participants $(72 \%)$ were opposed to the idea of separate work on grammar and doubt its usefulness, almost the same percent $(75 \%)$ of them contended that grammatical knowledge can be grasped if language learners are exposed to language and are allowed to use language for communicative purposes (Table 3). In the interview also the interviewees unanimously disagreed with the 
The impact of EFL teachers' prior language learning experiences on their cognition about teaching grammar separate treatment of language skills and components. And although responses to the rest of the items pertaining to the same issue are not unequivocal, a glance at the responses to all the seven items indicates that the general trend is away from explicit and towards more implicit teaching of grammar.

Table 3

Necessity of explicit teaching of grammar

\begin{tabular}{|c|c|c|c|c|}
\hline & Relevant statements in the questionnaire $(\mathrm{Q})$ & Agree $(\%)$ & Disagree $(\%)$ & Undecided $(\%)$ \\
\hline 1 & $\begin{array}{l}\text { The separation of work with a grammar focus from the } \\
\text { rest of the language syllabus is useful for students. }\end{array}$ & 10 & 72.5 & 17.5 \\
\hline 2 & $\begin{array}{l}\text { Students need to be consciously aware of a structure's } \\
\text { form and its function before they can use it proficiently. }\end{array}$ & 32 & 47.5 & 22.5 \\
\hline 3 & $\begin{array}{l}\text { Formal instruction helps learners to produce } \\
\text { grammatically correct language. }\end{array}$ & 42.5 & 20 & 37.5 \\
\hline 4 & $\begin{array}{l}\text { Students need a conscious knowledge of grammar in } \\
\text { order to improve their language. }\end{array}$ & 50 & 30 & 20 \\
\hline 5 & $\begin{array}{l}\text { Student use of language does not involve conscious } \\
\text { knowledge of the grammatical system and how it works. }\end{array}$ & 33 & 42.5 & 22.5 \\
\hline 6 & $\begin{array}{l}\text { Grammar knowledge developed through separate work } \\
\text { on grammar cannot be of much help to learners in } \\
\text { natural communication. }\end{array}$ & 55 & 32.5 & 12.5 \\
\hline 7 & $\begin{array}{l}\text { Grammar is best taught through work which focuses on } \\
\text { message. }\end{array}$ & 51 & 27 & 22 \\
\hline 8 & $\begin{array}{l}\text { Students can learn grammar through exposure to } \\
\text { language in natural use. }\end{array}$ & 75 & 12.5 & 12.5 \\
\hline
\end{tabular}

The next issue within grammar teaching strategies has to do with inductive/deductive modes of introducing grammatical structures. Five items have been employed to figure out where the teachers stand in this regard. In line with the above tendency, the teachers tended to generally favor inductive teaching of grammar rather than deductive teaching of it. As Table Four indicates, the most unequivocal responses belonged to the presentation of grammatical items 'within a complete text'; that is, almost four-fifth (77.5\%). This idea was defended in the participants' responses to interview questions as well. In fact, all the 14 participants unanimously pointed to the significance of contextualized presentation of grammar. It is interesting to know that a majority of the participants $(51 \%)$ even claimed that students can learn grammar if focus of teaching is on message rather than form. In the interview as well 5 out of 14 participants preferred implicit teaching of language. For instance, one teacher held that

In an ideal condition, I surely prefer implicit teaching ...if we were able to learn language in the rich environment full of language input and interaction [in and out of class], then implicit teaching of grammar would really be fruitful.

\section{Table 4}

Modes of teaching grammar

\begin{tabular}{clcc}
\hline \multicolumn{1}{c}{ Relevant statements in the questionnaire (Q) } & Agree (\%) & Disagree (\%) & Undecided (\%) \\
\hline 9 & $\begin{array}{l}\text { Explicit discussion of grammar rules is helpful for } \\
\text { students. }\end{array}$ & 30 & 27.5 \\
10 & $\begin{array}{l}\text { Grammar is best taught through a focus on individual } \\
\text { structures }\end{array}$ & 45 & 30 \\
11 & $\begin{array}{l}\text { Comparison and contrast of individual structure is helpful } \\
\text { for students learning grammar. }\end{array}$ & 75 & 25 \\
12 & $\begin{array}{l}\text { Students learn grammar more successfully if it is } \\
\text { presented within a complete text. }\end{array}$ & 7.5 & 15 \\
\hline
\end{tabular}


As to the desirability or otherwise of correcting students' errors, there seems to be a divide among the participants, though the weight of the responses tilted rather in favor of the correction of the global errors (47\% vs. 30\%). As far as interviews were concerned, the participants were not of the same opinion on this issue. Nine out of fourteen teachers asserted that they will benefit from indirect error correction strategies, the reason being the import of learners' affect. One participant, for instance, cited that

I attempt to avoid direct correction of errors. As you know, when you teach in a foreign language context, students are often reluctant to participate in class discussions. So if you correct them on the spot, they never dare to talk. As a result, I try to note their errors and correct them indirectly. (T 9)

Four other teachers explained that the type of strategy they may employ to correct learners' errors would highly depend on the type of errors (e.g. they won't correct local errors because these errors do not affect meaning seriously). Only one teacher stated that she would often correct students' errors on the spot:

I like to correct learners' errors on the spot. I think that this way will shock learners into concentration on errors and will affect their learning. (T 11)

\section{Table 5}

Desirability of correcting students' errors

The statements in the questionnaire $(\mathrm{Q})$

Agree (\%) Disagree (\%) Undecided (\%)

13 Teachers should only correct student errors of form which interfere with communication.

As to the last theme, i.e. use of grammar terminology, the participants were not much in agreement either, though more of them were against exploiting grammar terminology. More light will be shed on this numerical finding when it is complemented with the qualitative data. Two teachers out of the fourteen strongly believed in the significance of learning grammatical terms particularly for studying reference books on grammar.

It is so important for me to highlight grammatical items in my classes since I always introduce reference books as a supplementary source for grammar learning. So they must understand meta-language. (T 8)

Besides, six out to the 14 participants believed that just familiarity with the meta-language and the grammatical terms could be beneficial to learners. For instance, teachers numbered 1 and 4 cited respectively that

I told my students that I just want to introduce these grammatical items to you. I believe that since they do not want to learn English for academic purposes, only familiarity with terms will be enough for them.

It's better for learners to learn these terms gradually. I only introduce some key grammatical terms because I think that bombarding students with these terms will confuse them.

However, two other teachers were of the contention that the significance of grammar teaching was contingent upon the level of students, in that at higher levels students' proficiency in the target language allows them to benefit from the meta-language, this not being the case at lower levels. And finally, other teachers were completely against the use of grammar terminology and said that they normally ignore them in their teaching. 
The impact of EFL teachers' prior language learning experiences on their cognition about teaching grammar

Table 6

Desirability of benefiting from terminology in teaching grammar

\begin{tabular}{llccc}
\hline \multicolumn{2}{c}{ Relevant statement in the questionnaire (Q) } & Agree (\%) & Disagree (\%) & Undecided (\%) \\
\hline 14 & $\begin{array}{l}\text { It is useful to benefit from grammatical terminology } \\
\text { in teaching grammar. }\end{array}$ & 32.5 & 45 & 22.5 \\
\hline
\end{tabular}

\subsection{Sources of beliefs}

This section deals with findings of the study concerning the possible sources of the teachers' beliefs about grammar, grammar teaching and correcting learners' errors as well as use of grammar terminology. As mentioned in the methodology section, the participants were requested to think back and state what the sources of their beliefs about each of the above five items were. Table Seven and Figure One report the findings of the study. Table seven numerically details the participants' ideas about the sources of their beliefs about each of the themes (A-D), the latter depicting the overall weight of the three major sources of the participants' beliefs and their combinations.

\section{Table 7}

Participants' responses about the sources of their beliefs about the four major themes

\begin{tabular}{|c|c|c|c|c|c|c|c|c|c|c|c|c|}
\hline \multicolumn{7}{|c|}{ Frequency of Responses } & \multicolumn{6}{|c|}{ Valid percentage } \\
\hline & $\mathrm{a}$ & $\mathrm{b}$ & $\mathrm{c}$ & $\mathrm{ac}$ & $a b c$ & $\mathrm{mv}$ & $\mathrm{a}$ & $\mathrm{b}$ & $\mathrm{c}$ & ac & $\mathrm{abc}$ & $\mathrm{mv}$ \\
\hline A & 10 & 6 & 16 & 6 & 2 & - & 25 & 15 & 40 & 15 & 5 & 0 \\
\hline $\mathrm{B}_{1}$ & 7 & 3 & 19 & 8 & 1 & 2 & 17.5 & 7.5 & 7.5 & 20 & 2.5 & 5 \\
\hline $\mathrm{B}_{2}$ & 6 & 5 & 21 & 6 & 1 & 1 & 15 & 12.5 & 52.5 & 15 & 2.5 & 2.5 \\
\hline $\mathrm{C}$ & 4 & 3 & 25 & 7 & 1 & - & 10 & 7.5 & 62.5 & 17.5 & 2.5 & 2.5 \\
\hline $\mathrm{D}$ & 6 & 4 & 19 & 8 & 0 & 3 & 15 & 10 & 47.5 & 20 & 0 & \\
\hline
\end{tabular}

Note. a: prior language learning experiences, b: Teacher training course, c: Teaching experience, mv: missing value

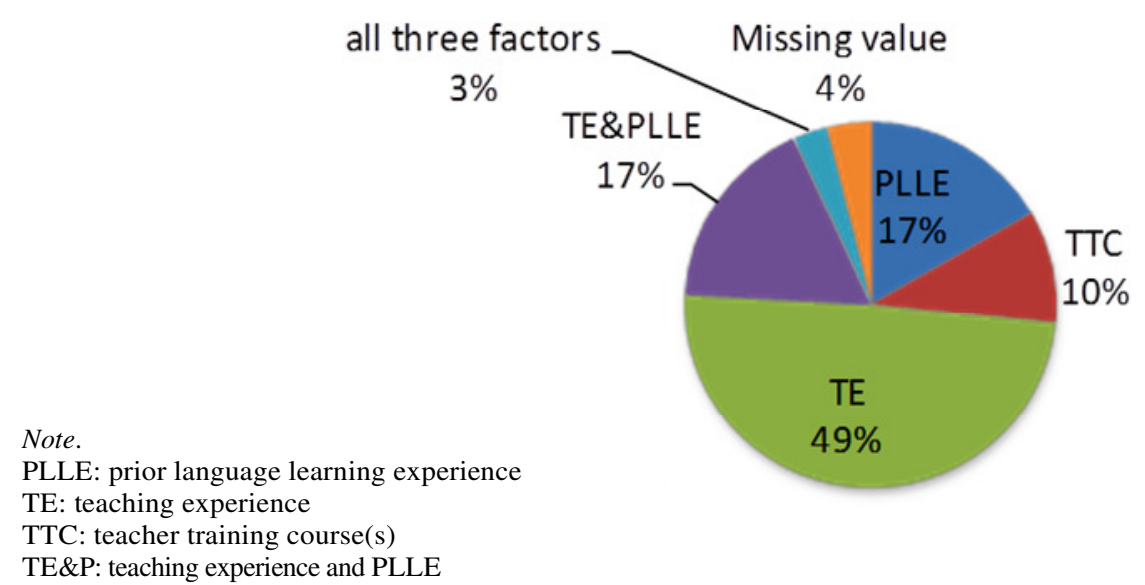

Figure 1. Different sources of the teachers' belief

As Figure 1 indicates, the participants assumed the greatest role for their teaching experience and claimed in (49\%) of the cases that their beliefs about grammar and grammar teaching could be traced in their teaching experience. The next source of belief was found to be the teachers' prior language learning experience, contributing directly about $17 \%$ to the formation of the participants' early beliefs. The participants also stated in about another $17 \%$ of the cases that what they currently believed about grammar and grammar teaching could be 
attributed to both their prior language learning experience and their teaching experience. This could reasonably mean that their beliefs had originally been formed from their learning experiences while they were still students and were approved and strengthened in the process of teaching. Hence it can be claimed that this percentage can also be attributed to prior language experience, the reason being that what the participants found reasonable and subsumed as part of their knowledge and belief was endorsed and reinforced rather than modified in the act of teaching itself, another indication of the influential role of the prior learning experiences. If so, the share of the prior language learning experience will rise dramatically, assuming a great percentage (34) of the beliefs still held by the teachers after a good number of years of teaching.

On the other hand, teacher training courses, which the participants had passed at the inception of their teaching were claimed to play the least significant role among the three major sources of belief, that is, $10 \%$ only. Similarly, there was a considerable corpus of the qualitative data which has provided evidence to support and vindicate the numerical data. The qualitative findings (Table 8 below) of the study further attest to the effects, both positive and negative, of teachers' prior language learning experiences on their current beliefs. In sum, there is both quantitative and qualitative evidence to confirm S. Borg's (2003b) idea about the continued influences of teachers' prior learning experience on their cognitions and classroom practices though the quality of such an influence could be unique for every individual teacher.

Table 8

Different effects of prior language learning experience

\begin{tabular}{|c|c|c|}
\hline Emerged episodes & out of $14 \mathrm{~T}$. & Examples \\
\hline $\begin{array}{l}\text { Potent } \\
\text { Effect }\end{array}$ & 7 & $\begin{array}{l}\text { "My experiences as a language learner have taught me that grammar learning } \\
\text { is significant." (T9) }\end{array}$ \\
\hline $\begin{array}{l}\text { Overrunning } \\
\text { Effect }\end{array}$ & 5 & $\begin{array}{l}\text { "Many times the supervisors have wanted me to use inductive strategy, but } \\
\text { I always teach grammar deductively." (T13) }\end{array}$ \\
\hline $\begin{array}{l}\text { Adverse } \\
\text { Effect }\end{array}$ & 3 & $\begin{array}{l}\text { "I like to correct my learners on the spot. I think this way will shock learner } \\
\text { into concentration on errors." (T10) }\end{array}$ \\
\hline $\begin{array}{l}\text { Counterproductive } \\
\text { Effect }\end{array}$ & 9 & $\begin{array}{l}\text { "I remember that our teachers often taught grammar deductively in a rigid } \\
\text { confusing manner. As a teacher I prefer to teach grammar inductively; I do not } \\
\text { believe in 'explicit teaching' of grammar" (T2) }\end{array}$ \\
\hline $\begin{array}{l}\text { Imitative } \\
\text { Effect }\end{array}$ & 4 & $\begin{array}{l}\text { "In my educational life, there were such influential teachers who significantly } \\
\text { affected me. Sometimes during my teaching I noticed that I unconsciously } \\
\text { implemented their strategies in my classes. This indicated that the effect was } \\
\text { so deep."(T12) }\end{array}$ \\
\hline $\begin{array}{c}\text { Emotive } \\
\text { Effect }\end{array}$ & 4 & $\begin{array}{l}\text { "She behaved friendly. I always try to behave my learners fairly as she did." } \\
\text { (T3) }\end{array}$ \\
\hline
\end{tabular}

\section{Discussions}

As mentioned above, the results of the study indicate that, as far as teacher cognition in grammar teaching is concerned, teachers' PLLE is a considerable contributor to teachers' current beliefs. The reason seems to be that, according to cognitive models of human learning, human mind is not a clean slate and does not start to learn new information from scratch; individuals process and understand new information (correctly or incorrectly) in light of their experience and prior knowledge and beliefs and often fail to remember, understand or apply ideas that have no connections to their experience and no context for acquiring meaning. 
The impact of EFL teachers' prior language learning experiences on their cognition about teaching grammar

The question is, 'what is the reason for the durability of teachers' beliefs arising from their prior learning experience? The response seems to lie in Pajares' characterization of human belief. In his comprehensive review of the literature on beliefs, Pajares (1992, p. 324) contends that teachers' beliefs, including their prior learning experiences as core reference point, are characterized by an array of 'fundamental assumptions some of which often impede teachers' subsequent educations'. Building upon the assumptions proposed by Pajares, teacher beliefs can be considered as something 'affect-laden, self-validating filter-like concepts which are ... often robust and resistant to change'[italics added].

The centrality of belief inflexibility as one of the major issues in teacher education has been raised in a considerable body of research (Calderhead \& Robertson, 1991 as quoted in Farrell, 1999; Kagan, 1992; Pajares, 1992; Richards, 1998; Richards, Gallo, \& Renandya, 2001). The major reason why beliefs persist for so long and are not easily affected by later education seem to be that as Pajares (1992) maintains they tend to be grounded in powerful episodic memories, that is, those memories of life experiences which center around the person himself and basically involve the element of time. Once beliefs are formed individuals have a tendency to build explanations around those beliefs, regardless of whether such explanations are accurate or are mere inventions. In fact, teachers often use whatever justifications necessary to appear congruent with their beliefs, and turn conflicting evidence into support for their beliefs, even when beliefs contradict one another. Pajares also claims that

The earlier a belief is incorporated into the belief structure, the more difficult it is to alter, for these beliefs subsequently affect perception and strongly influence the processing of information. It is for this reason that newly acquired beliefs are more vulnerable (1992, P. 317).

Besides their continued influence, beliefs arising from PLLEs often provide teachers with a number of episodically-based imitative misconceptions (Lortie, 1975) which may hinder their professional learning and lead to inappropriate teaching behaviors. This is because, as students, they have had no idea of their own teachers' private intentions and personal reflections on classroom events. And they had rarely participated in selecting goals, making preparations, or analyzing the teaching events to arrive at the underlying principles and gaining insights. What students learn about teaching, then, is intuitive and imitative rather than explicit and analytical.

Hence in teacher education courses, it is incumbent upon teacher educators to expose the student- teachers' as well as in-service teachers' beliefs about different aspects of learning and teaching. This will help keep unexamined personal experiences from being overgeneralized without an opportunity for analysis and perspective. In other words, they should help student teachers 'to become aware of and to articulate their own knowledge about teaching - knowledge that is often tacit and unexamined - and to bring it to the surface for examination, reflection and even challenge' (Darling-Hammond, 2005, p. 435). If the teachers' initial understanding is not engaged, they may fail to grasp the new concepts and information, or they may learn them for purposes of a test but revert to their preconceptions outside the classroom.

Unfortunately, teachers are often heard to say that pre-service and in-service teacher education courses are of little help to them in their teaching. This seems to be mainly due to the fact that some of these courses are too short to address these preconceptions at all, and have little capacity for changing these preconceptions. In other, longer term teacher education courses students are only presented with the latest theories of language learning and the current views about language teaching as well as with how to teach the four language skills, assuming that the trainees will learn and apply them outright in their teaching. The fact of the matter is that what teachers are taught in their teacher education programs will most likely be filtered through their prior experiences and preexisting beliefs, which act as intuitive screens through which they perceive the new information. This can only be rectified if there is a shift of focus in teacher education courses from a mere presentation of latest theories of learning and models of teaching to providing opportunities for the teacher trainees to present their beliefs about learning and teaching for scrutiny, analysis and evaluation. Only then may the trainees come to 
notice to what extent their unanalyzed, problematic beliefs, which have often been reached from single instances, are valid and generalizable to other contexts. It is highly likely that modifications will be made to the trainees' 'preconceptions if their apprenticeship of observation is used as a springboard from which to begin the process of conceptual and behavioral change' (Darling-Hammond \& Bransford, 2005, p. 370). According to Kontra

In order to facilitate change it is vital to open up trainees' thinking and to help them articulate their deeply rooted preconceptions about language teaching'. Without experiencing this change, the trainee might be left with a fossilized conceptual framework into which new techniques rooted in a different theory cannot be fitted, and where copying these techniques or activities will result in a mismatch (1997, p. 245)

\section{Conclusions and implications}

The study examined the sources of in-service teachers' beliefs about grammar, i.e., the role of grammar in learning a second language, the necessity of conscious teaching of grammar, mode of teaching grammar, use of terminology in teaching grammar as well as correction of grammatical errors. The findings of the study revealed that teachers' current beliefs, or more accurately preconceptions, seem to arise, to a considerable extent, from their prior language learning experiences, and often persist even where they contradict with the current conceptualizations as presented in the teacher education courses and even with the realities of the practice of teaching. The reason seems to be that these mostly ungrounded beliefs together form a world view according to which the upcoming events will be interpreted, and due to their firm establishment they leave no room for evaluation and revision.

The results of the study can provide some implications for teacher education courses, practicing teachers themselves as well as for research in teacher preparation. As to teacher education programs, we need to once again emphasize the already theoretically acknowledged yet practically insufficiently adhered to advice that to be effective, teacher education courses are to expose and challenge teachers' unanalyzed, incoherent beliefs for maximum efficiency. Literature indicates that teacher education courses still ignore teachers' mental lives as the starting point to work upon and to change. For instance, Johnson (2009, p. 21) contends that

the content of L2 teacher education programs(what L2 teachers need to know) had been largely drawn from our parent disciplines, most notably theoretical linguistics and SLA, and very little from the work of the L2 teachers and L2 teaching itself. Even today, one needs to look no further than the Directory of Teacher Education in TESOL in the United States and Canada (TESOL 2007) to see that the knowledge of the formal properties of language and theories of SLA continue to be positioned as foundational knowledge for the professional preparation of L2 teachers.

Regarding the implication of the study for the teachers themselves, considering the limiting aspects of PLLEs covered in the study in particular their stability, teachers are well advised to probe into their prior beliefs to align them with the empirical knowledge of teaching and pedagogy, or it is highly likely that they will teach the way they were taught. This is because 'moving beyond the apprenticeship of observation is an important step in the developmental process of learning to teach' (Johnson, 1999, p.22). As S. Borg (2006) put it, acknowledging these prior cognitions, making them explicit in order to examine and reconsider them in the light of new information and experience are thus important elements in the process of teacher learning even for those teachers who have already garnered years of teaching experiences.

The study can also have some implications for research. Since teachers' experiences are of crucial importance, the ways in which this type of knowledge can be examined, tuned and integrated into their practical knowledge should be clearly investigated and documented by researchers and preparation-service and in-service program developers. The matter of the 'belief development' also is supported by Darling-Hammond (2005, p. 400) contending 'the starting point for learning is always one's own prior knowledge, which must be 
The impact of EFL teachers' prior language learning experiences on their cognition about teaching grammar

connected in some way to new learning opportunities' in teacher education programs. To this end, due to the significance of cultural and social context of teaching in teachers' belief development (Özmen, 2012), educational programs need to focus their attention on teachers' initiatives (i.e. prior knowledge) and needs in every specific context to design more effective programs. This is particularly true for EFL teachers' who are 'still in language experiences' (Warford \& Reeves, 2003 in Li, 2012, p. 36), at least in early stages of their educational life, and whose knowledge base mostly is transmission- laden and experiential.

\section{References}

Almarza, G. (1996). Student foreign language teachers' growth. In D. Freeman \& J. C. Richards (Eds.), Teacher learning in language teaching (pp. 50-78). Cambridge: Cambridge University Press.

Aoulou, E. H. (2011), Understanding how ESOL pre-services teachers' prior experiences and background shape their processes of becoming L2 (reading) teachers. Doctoral dissertation, Georgia State University, Atlanta, Georgia.

Arioğul, S. (2007).Understanding foreign language teachers' practical knowledge: What's the role of prior language learning experience? Journal of Language and Linguistic Studies, 3(1), 168-181.

Atay, D. (2004). Collaborative dialogue with student teachers as a follow-up to teacher in-service education and training. Language Teaching Research, 8(2), 143- 162. http://dx.doi.org/10.1191/13621688041r1380a

Bailey, K. M., Bergthold, B., Braunstein, B., Fleischman, N. J., Holbrook, M. P., Tuman, J., Waissbluth, X., \& Zambo, L. J. (1996). The language learners' autobiography: examining the apprenticeship of observation. In D. Freeman \& J. C. Richards (Eds.), Teacher learning in language teaching (pp.11-30). New York: Cambridge University Press.

Best, W., \& Kahn, J. V. (2006). Research in education (10th ed.). Boston: Pearson.

Borg, M. (2004). The apprenticeship of observation. ELT Journal, 58(3), 274-276. http://dx.doi.org/10.1093/elt/58.3.274

Borg, S. (2003a). Second language grammar teaching: practices and rationales. Ilha Desterro, 41, 155-183.

Borg, S. (2003b). Teacher cognition in language teaching: a review of research on what language teachers think, know, believe, and do. Language Teaching, 36(2), 81-109. http://dx.doi.org/10.1017/S0261444803001903

Borg, S. (2005).Teacher cognition in language teaching. In K. Johnson (Ed.), Expertise in Second Language Learning and Teaching (pp. 190-209). Basingstoke: Palgrave Macmillan.

Borg, S. (2006). Teacher cognition and language education: Research and practice. London: Continuum.

Burgess, J., \& Etherington, S. (2002). Focus on grammatical form: Explicit or implicit? System, 30, 433-435. http://dx.doi.org/10.1016/S0346-251X(02)00048-9

Crandall, J. (2000). Language teacher education. Annual Review of Applied Linguistic, 20, 34-55. http://dx.doi.org/10.1017/S0267190500200032

Darling-Hammond, L., \& Bransford, J. (2005). Preparing teachers for a changing world. San Francisco: Jossey-Bass.

Donaghue, H. (2003). An instrument to elicit teachers' beliefs and assumptions. ELT journal, 57(4), 344-351. http://dx.doi.org/10.1093/elt/57.4.344

Dörnyei, Z. (2007). Research methods in applied linguistics. Oxford: Oxford University Press.

Farrell, T. S. C. (1999). The reflective assignment: Unlocking Preservice teachers' beliefs on grammar teaching. RELC Journal, 30(2), 1-17. http://dx.doi.org/10.1177/003368829903000201

Farrell, T. S. C. (2006). The teacher is an octopus': Uncovering pre-service English language teachers' prior beliefs through metaphor analysis. RELC Journal, 37(2), 236-248.

http://dx.doi.org/10.1177/0033688206067430

Freeman, D. (2002). The hidden side of the work: Teacher knowledge and learning to teach. Language Teaching, 35, 1-13. http://dx.doi.org/10.1017/S0261444801001720

Golombek, P. R. (1998). A study of language teachers' personal practical knowledge. TESOL Quarterly, 32(3), 447-464. http://dx.doi.org/10.2307/3588117 
Rayati Damavandi, R. \& Roshdi, M.

Hammerness, K., Darling-Hammond, L., Bransford, J., Berliner, D., Cochran-Smith, M., McDonald, M., \& Zeichner, K. (2005). How teachers learn and develop. In L. Darling-Hammond \& J. Bransford (Eds.), Preparing teachers for a changing world what teachers should learn and be able to do (pp. 358-390). San Francisco: Jossey-Bass.

Hedge, T. (2000). Teaching and learning in the language classroom. Oxford: Oxford University Press.

Johnson, K. E. (1999). Understanding language teaching: Reasoning in action. Boston, MA: Heinle \& Heinle.

Johnson, K. E. (2009). Trends in second language teacher education. In A. Burns \& J. C. Richards (Eds.), The Cambridge guide to second language teacher education (pp. 20-29). Cambridge: Cambridge University Press.

Kagan, D. M. (1992). Professional growth among pre-service and beginning teachers. Review of Educational research, 62,129-169.

Karavas, E., \& Drossou, M. (2010). How amenable are student teacher beliefs to change? A study of EFL student teacher beliefs before and after teaching practice. In A. Psaltou-Joycey \& M. Matheoudakis (Eds.), Advances in research on language acquisition and teaching: Selected papers (pp. 261-276). Greek Applied Linguistic Association, Thessaloniki.

Kontra, E. H. (1997). Reflections on methodology training. ELT journal, 51(3), 243-248. http://dx.doi.org/10.1093/elt/51.3.242

Li, L. (2012). Belief construction and development: Two tails of non-native English speaking student teachers in a TESOL program. Novitas-ROYAL (Research on Youth and Language), 6(1), 33-58.

Lortie, D. C. (1975). Schoolteacher: A sociological study. Chicago: University of Chicago Press.

Özmen, K. (2012). Exploring student teachers' beliefs about language learning and teaching: A longitudinal study. Current Issues in Education, 15(1), 1-16.

Pajares, M. F. (1992). Teachers' beliefs and educational research: Cleaning up a messy construct. Review of education research, 62(3), 307-332.

Peacock, M. (2001). Pre-service ESL teachers' beliefs about second language learning: Longitudinal study. System, 29, 177-195. http://dx.doi.org/10.1016/S0346-251X(01)00010-0

Richards, J. C. (1998). Beyond training. Cambridge: Cambridge University Press.

Richards, J. C., Gallo, P. B., \& Renandya, W. A. (2001). Exploring teachers' beliefs and the processes of change. The PAC Journal, 1, 43-64.

Su, Y. N. (2012). Teach to live or live to teach: A case study on the educational beliefs of displaced teachers in Taiwan. International Journal of Research Studies in Education, 1(1), 3-20. http://dx.doi.org/10.5861/ijrse.2012.v1i1.2

Wright, T. (2010). Second language teacher education: Review of recent research on practice. Language Teaching, 43(3), 259-296. http://dx.doi.org/10.1017/S0261444810000030 


\section{Appendix}

A. The questionnaire

Dear colleague

I am interested in investigating teachers' approaches towards grammar teaching and factors involved in the formation of their ideas. Your participation in this survey will help me to explore this topic better Please kindly spare a few minutes of your time to complete this questionnaire. Your responses to this questionnaire will be treated with the most confidence. Thank you for your cooperation.

Very important: Read the instruction below before responding to the questionnaire.

Please indicate how far you agree with the following statements about the role and teaching of grammar in teaching English. If you agree strongly circle a 5 on the scale, if you strongly disagree circle a 1 on the scale. Circle one of the other numbers depending on the extent to which you agree with the statement. Please feel free to add any comments you wish to make (in Farsi if possible).

The role of grammar in language is as: (please answer for each option)

1. A framework for the rest of the language: a basic system to build everything else on. strongly disagree $\quad \begin{array}{llllll}1 & 2 & 3 & 4 & 5 & \text { strongly agree }\end{array}$

2. The building blocks of language which are combined to form a whole. strongly disagree $\quad \begin{array}{llllll}1 & 2 & 3 & 4 & 5 & \text { strongly agree }\end{array}$

3. Something which is added on to language proficiency: it makes language production more accurate. strongly disagree $\quad \begin{array}{llllll}1 & 2 & 3 & 4 & 5 & \text { strongly agree }\end{array}$

4. An equal pillar in supporting language proficiency. (Other pillars could be knowledge about pronunciation, appropriacy or culture etc.)

$\begin{array}{lllllll}\text { strongly disagree } & 1 & 2 & 3 & 4 & 5 & \text { strongly agree }\end{array}$

A. The above belief of mine concerning the role of grammar in language learning is mainly based on my

a) Language learning experiences

b) Teacher training course(s)

c) English teaching experiences

Comments (if any): 
Rayati Damavandi, R. \& Roshdi, M.

5. Students can learn grammar through exposure to language in natural use. strongly disagree $\quad 1 \quad 2 \quad 2 \quad 3 \quad 4 \quad 5 \quad$ strongly agree

6. Formal instruction helps learners to produce grammatically correct language. strongly disagree $\quad 1 \quad 2 \quad 2 \quad 3 \quad 4 \quad 5 \quad$ strongly agree

7. Student use of language does not involve conscious knowledge of the grammatical system and how it works.

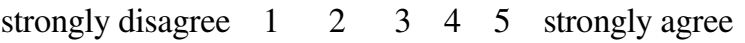

8. Students need a conscious knowledge of grammar in order to improve their language. strongly disagree $\quad 1 \quad 2 \quad 2 \quad 3 \quad 4 \quad 5$ strongly agree

9. Grammar knowledge developed through separate work on grammar cannot be of much help to learners in natural communication.

strongly disagree $\quad 1 \quad \begin{array}{llllll}1 & 2 & 3 & 4 & 5 & \text { strongly agree }\end{array}$

10. Students need to be consciously aware of a structure's form and its function before they can use it proficiently

strongly disagree $\quad 1 \quad \begin{array}{lllllll} & 2 & 3 & 4 & 5 & \text { strongly agree }\end{array}$

11. The separation of work with a grammar focus from the rest of the language syllabus is useful for students. strongly disagree $\quad 1 \quad \begin{array}{llllll}1 & 2 & 3 & 4 & 5 & \text { strongly agree }\end{array}$

B. The above ideas regarding the necessity/redundancy of grammar teaching is mainly based on

a) My language learning experiences

b) My teacher training course(s)

c) My English teaching experiences

Comments (if any):

12. Grammar is best taught through work which focuses on message. strongly disagree $\quad 1 \quad \begin{array}{llllll}1 & 2 & 3 & 4 & 5 & \text { strongly agree }\end{array}$

13. Students learn grammar more successfully if it is presented within a complete text. strongly disagree $\quad 1 \quad \begin{array}{lllllll} & 2 & 3 & 4 & 5 & \text { strongly agree }\end{array}$

14. Grammar is best taught through a focus on individual structures.

strongly disagree $\quad 1 \quad \begin{array}{lllllll} & 2 & 3 & 4 & 5 & \text { strongly agree }\end{array}$

15. Explicit discussion of grammar rules is helpful for students. strongly disagree $\quad 1 \quad \begin{array}{lllllll} & 2 & 3 & 4 & 5 & \text { strongly agree }\end{array}$

16. Comparison and contrast of individual structures is helpful for students learning grammar. strongly disagree $\quad 1 \quad 2 \quad \begin{array}{llllll} & 2 & 4 & 5 & \text { strongly agree }\end{array}$ 
The impact of EFL teachers' prior language learning experiences on their cognition about teaching grammar

C. These beliefs concerning how grammar is to be taught mainly derives from

a) My language learning experiences

b) My teacher training experiences

c) My English teaching experiences

Comments (if any):

17. Teachers should only correct student errors of form which interfere with communication. $\begin{array}{lllllll}\text { strongly disagree } & 1 & 2 & 3 & 4 & 5 & \text { strongly agree }\end{array}$

D. My beliefs concerning how students' errors are to be corrected are mainly based on my

a) Language learning experiences

b) Teacher training experiences

c) English teaching experiences

Comments (if any):

18. It is useful to benefit from grammatical terminology in teaching grammar. $\begin{array}{llllllll}\text { strongly disagree } & 1 & 2 & 3 & 4 & 5 & \text { strongly agree }\end{array}$

E. My ideas regarding the use of terminology in grammar teaching basically derives from .......

a) My language learning experiences

b) My teacher training course(s)

c) My English teaching experiences

Comments (if any): 
Rayati Damavandi, R. \& Roshdi, M. 